metoclopramide on plasma cholinesterase activity. Can J Anaesth 1988; 35: 476-8.

2 Kao YJ, Turner DR. Prolongation of succinylcholine block by metoclopramide. Anesthesiology 1989; 70: 905-8.

3 Zapf PW, Coghlan CHM. A kinetic method for the estimation of pseudocholinesterase using naphthyl acetate substrate. Clin Chim Acta 1974, 43: 237-42.

4 Kalow W, Genest $K$. A method for the detection of atypical forms of human serum cholinesterase. Determination of dibucaine numbers. Can J Biochem Physiol 1957 , 35: $339-46$.

Jay Kambam MD

Winston Parris MD

John J. Franks MD

B.V.R. Sastry Ph D

Rebecca Naukam Bs

Bradley E. Smith MD

Department of Anesthesiology

Vanderbilt University Medical Center

Nashville, TN, 37232-2125

\section{Contamination of syringes}

To the Editor:

The recent article by Lessard et al. showed the risk to the patient of bacterial contamination with multiple use of syringes to be negligible but emphasized the risks from viral contamination. ${ }^{1}$ A questionnaire was distributed to all members of anaesthesia departments of the Universities of Pittsburgh and Michigan in the general adult, paediatric and obstetric divisions (five hospitals total) to quantitate the frequency of common syringe techniques. Anonymous responses were collected and evaluated from 139 personnel: 48 anaesthetists, 48 CRNAs, 31 residents and 12 student CRNAs. Respondents indicated that they routinely, frequently, rarely or never used common syringe techniques $30.9,41.7,17$ and 10 per cent of the time, respectively. Almost all personnel ( 98 per cent) reuse multiple dose vials opened by unknown persons and 75 per cent refill common syringes from multi-dose vials without discarding them subsequently. Common syringes were used by 18 per cent, when blood products were given through the IV line.

In the 1950's it was recognized that reusing common syringes on multiple patients could transmit diseases and that changing needles was quite ineffective in lowering the danger of crossinfection. ${ }^{2,3}$ During needle removal from the syringe, the needle contents are aspirated up to the syringe tip before the air lock is broken at the needle hub. The lumen of intravenous lines is frequently and occultly contaminated with blood and $10^{-7}$ to $10^{-9} \mathrm{ml}$ of blood can transmit hepatitis. ${ }^{4,5}$ The reuse of these needles or syringes clearly presents a danger to patients and the health care providers themselves, who may acquire hepatitis from them during use or recapping. The contamination of IV tubing can only be excluded when the IV is started and continuously observed and manipulated by one person alone. Hepatitis is transmitted via transfusion and/or operation as independent factors: $\mathbf{3 . 3}$ per cent of non-Iransfused patients acquire hepatitis from unknown sources versus 5.6 per cent of transfused patients. $^{6-9}$

Viral transmission may additionally occur when using multi-dose vials in conjunction with common syringe techniques. Hepatitis virus is stable on dry surfaces for one week and may survive longer in suitable aqueous states. ${ }^{10}$ Bacteriological studies of multi-dose vials or syringes are not useful in documenting contamination, as contained bacteriostatic agents rapidly eliminate bacteria. " There is no evidence that bacteriostatic agents will destroy all introduced pathogenic virus and manufacturers recommend that only sterile equipment is used to enter multidose vials.

Although high rates of common syringe technique utilization may not be encountered in all institutions, widespread practice is likely, in spite of recommendations to the contrary. ${ }^{12}$ These techniques violate guidelines which exist to protect hospital workers from exposure to blood-borne infections. ${ }^{13,14}$ The Center for Disease Control, however, has no specific policy regarding common syringes. Universal precautions guidelines are apparently needed to preclude nosocomial infection of patients.

Until research proves that the use of common syringe techniques is safe they should be abandoned.

\section{Paul Martin Kempen MD}

Instructor

Department of Anesthesiology

University of Pittsburgh

\section{REFERENCES}

1 Lessard MR, Trepanier CA, Gourdeau M, Denault $P H$. A microbiological study of the contamination of the syringes used in anaesthesia practice. Can J Anaesth 1988; 35: 567-9.

2 Fleming $A, O_{g i l v i e} A C$. Syringe needles and mass inoculation technique. Br Med J 1951; 1: 543-6.

3 Lutz CT, Bell CE, Wedner HJ, Krogstad DJ. Allergy testing of multiple patients should no longer be performed with a common syringe. N Engl J Med 1984; 310: 1335-7.

4 Hein HAT, Reinharl RD, Wansbough SR, Jaizen PAH, Giesecke $A H$. Recapping needles in anesthesia: is it safe? Anesthesiology 1987; 67: Al61

5 Koepke JW, Reller LB, Masters HA, Selner JC: Viral 
contamination of intradermal skin test syringes. Ann Allergy 1985; 55: 776-8.

6 Stevens $C E$, Aach RD, Hollinger FB et al. Hepatitis B virus antibody in blood donors and the occurrence of non- $A$, non-B hepatitis in transfusion recipients. Ann Int Med 1984; 101: 733-8.

7 Gallo $C$, Gaeta GB, Galanti B, Giusti $G$. The role of surgery in transmitting "post transfusion hepatitis." Eur J Epidemiol 1986; 2: 95-8.

8 Kiyasawa K, Gibo Y, Sodeyama $T$, Furuta $K$, Yoshizawa, Furuta $S$. Possible infectious causes in 651 patients with viral hepatitis during a 10 year period (1976-1985). Liver 1987; 7: 163-8.

9 Regli PJ, Joller-Jemelka I, Grob PJ. Hepatitisepidemiologie-Kanton Zuerich und Umgebung 1976. Schweitz. med Wschr. 1977; 107: 769-79.

10 Bond WW, Favero MS, Petersen NJ, Gravelle Cr, Ebert $J W$, Maynard JE. Survival of hepatitis B virus after drying and storage for one week. Lancet 1981; 1: 550-1.

11 Bawden JC, Jacobson JA, Jackson JC, Anderson RK, Burke JP. Sterility and use patterns of multiple dose vials. Am J Hosp Pharm 1982; 39: 294-7.

12 Heseltine $P$. Anesthesiologists should not give IV medications with a common syringe. Hospital Infection Control, June 1986, 84-5.

13 Berry AJ. Practice advisory prevention of blood bome infections (hepatitis B and AIDS). ASA Newsletter 1988; 52: 5-6.

14 Center for Disease Control: Recommendations for the prevention of HIV transmission in health care settings. MMWR Suppl. 1987; 36: 2S-18S.

\section{REPLY}

We were very interested by the survey Dr. Kempen conducted on the prevalence of the use of a common syringe technique. The high percentage of practitioners who use this technique was no surprise to us. Indeed, an informal survey had showed us that this practice is also very frequent in Canada. We agree on most of the points raised by Dr. Kempen. However, we feel that there is a serious lack of daia on the incidence of $I V$ contamination by blood in the operating room setting. Further studies are needed to provide objective data on this occurrence and the factors altering it.

We agree with Dr. Kempen that guidelines on this issue should be proposed. However, research should be directed toward the identification and quantification of the risk of disease transmission involved. Such studies would allow both the CAS and the ASA to propose guidelines that would be both scientifically and ethically sound.

Claude A. Trépanier MD FRCPC

Martin R. Lessard MD

Pierre H. Denault MD FRCPC

Département d'anesthésie

Hóspital de l'Enfant-Jésus

Québec

\section{A portable anaesthetic monitor- ing trolley for labour room placement of epidurals}

In obstetrics, the placement of an epidural catheter and the institution of epidural anaesthesia for labour requires an appropriate level of patient monitoring and the ready availability of resuscitation equipment. ${ }^{1}$ At our institution, the rooms in which the patients labour were not designed for special procedures and lack appropriate lighting, monitoring equipment and storage space which are necessary to safely begin an epidural anaesthetic. Until recently, we have moved labouring patients across to one of our operating/delivery rooms for the placement of the epidural catheter and the initial local anaesthetic injection. Whereas this arrangement provides the best environment for the anaesthetist to monitor and manage the patient, the transfer of a patient is disnuptive during her labour and an inefficient use of nursing staff.

To enable us to place epidural catheters safely and begin epidural anaesthesia in the labour rooms, we have developed a portable epidural anaesthetic trolley which combines maternal monitoring equipment, a light source, epidural placement supplies and resuscitation drugs and equipment together on a mobile trolley.

The trolley is a standard four-drawer anaesthetic cart measuring 20 inches wide, 18 inches deep, and 34 inches high (Figure). We have mounted a pulse oximeter (Nellcor ${ }^{\oplus}$ N100, Nellcor Incorporated, Hayward, California) and an automatic blood pressure cuff (Critikon ${ }^{\circledR}$ Dinamap 1846P, Critikon Corporation, Tampa, FJorida) to the table and equipped it with a medically approved multiple electrical outlet power bar. An articulated incandescentfluorescent light source is also permanently mounted to the table top.

The trolley is stocked with epidural trays, local anaesthetic solutions and supplies for beginning intravenous infusions. Masks, caps and sterile gloves are stocked for the sterile procedure. Resuscitation/intubation drugs and equipment are stored in the drawers and are prepared three times a week, ready for immediate use.

All labour rooms have independent oxygen and suction sources as well as oral airways, a resuscitation bag and mask. These are maintained at an appropriate level of readiness. Beds in these rooms are all capable of leg-elevation and Trendelenburg positioning and have removable headboards.

When patients request epidural anaesthesia, the trolley is moved to the patient's bedside and monitors are attached. Epidural anaesthesia can then be performed safely with the same degree of patient monitoring and 